\title{
Exploring the Concept of Social Change in the Thought of Ibn Khaldun
}

\author{
Dare Ojo Omonijo \\ Department of Student Industrial Work Experience Scheme, \\ Covenant University, Ota, Nigeria; \\ Department of Sociology, Olabisi Onabanjo University, \\ Ago-Iwoye, Nigeria \\ Michael C. Anyaegbunam \\ Department of Psychology, \\ Nnamdi Azikiwe University, Nigeria
}

DOI: https://doi.org/10.36941/ajis-2020-0105

\section{Abstract}

The concept of social change could be considered an ever-constant phenomenon in human society. This is because virtually nothing has ever remained static since the advent of man and his society. Thus, issues surrounding social change have occupied the mind of scholars for many centuries. Consequently, its applicability to social life issues has gained prominence among authors across cultures. In spite of this, however, it appears the contribution of Ibn Khaldun to social change as it relates to Christian religion has not been adequately addressed in academic and the Christian literature, mostly from tertiary institutions in Africa. This inadequacy may have prevented the enrichment of the literature on social change and the Christian religion. The present article intends to address this flaw in knowledge. It tries to compare the ideas of Western scholars on social change with that of Ibn Khaldun and highlighted similarities and differences which could be used to corroborate or negate the existing literature and further research. Data from a secondary source was used in this article while content analysis served as the methodology. Further to that, the article analyzed areas of food for thought in the change that occurred in the Christian religion, using the West and Africa as a point of reference The article in its concluding remarks argued that Africans may be in control of Christian religion currently, but the likelihood of losing it in the nearest future could be very bright, judging from the escalation of corruption in the faith which Ibn Khaldun argues is usually responsible for a decay of every civilised region. The escalation of corruption has been responsible for the underdevelopment of the continent and needs to be dealt with to advance the continent.

Keywords: Exploring, Ibn Khaldun, theory, social change, Christian religion

\section{Introduction}

From the world go, it is evident in the literature that no human society has ever remained static Mishra, (2016); the force of social change has always been altering the society and human activities. MacIver and Page, (1949) cited in Mishra, (2016) view social change as the alteration in the structure and institutions that constitute the society as well as the social relations involving her inhabitants. While some of such transformations are beneficial to society, some other alterations are conflicting and destructive depending on the specific factors predispose the change. Such factors include good or 
bad weather and the aims of persons or groups of persons that orchestrate the change (selfless or selfish agents of change) (Mishra, 2016).

Out of the above mentioned factors, the roles of human beings in social change could be more rigorous. This is because humans do not have control of climate and weather, but they have control over their lives. However, how to regulate human lives is seemed to be very intricate and therefore poses serious challenges to existence. For instance, observation has shown that the positive impact of modernity can be felt across the world and obnoxious cultural practices, most especially from Africa are expected to fade away but the addiction of some persons, groups or races to such practices could prevent social change from taking its course because they are strictly embedded in the culture (Rejulin, 2019). The practice of female genital mutilation which has greatly affected a lot of women in Africa is one of such practices (Omonijo, Anyaegbunam, Okoye, Nnatu, Okunlola, Adeleke, Olowookere, Adenuga and Olaoye, 2019). In the opposite, some cultural practices that hinder development which is expected to be replaced with new ways of life to enhance development in most developing countries are still in vogue constituting impediments to human progress because some persons, groups, ethnic groups etc. are so addicted to them due to their culture. Polygamous family, giving birth to many children and preference for a male child among others are in this category.

The foregoing could be regarded as a hindrance to cultural diffusion that stimulate development in human society. Since the culture itself is dynamic, the people who practice the culture should constantly adapt to changes that are needed to transform human society and her inhabitants from one level of development to another. This is because life could only be meaningful when humanity strives to adapt to situations or circumstances which could make life pleasant at the appropriate time; failure to do so could be disastrous to the society and human progress.

Previous studies have also shown that social change can be compelled by some unique and systemic factors or the combination of both (Mishra, 2016). While the unique factors involve weather and climate, religious, cultural, economic, scientific and technological forces, systemic factors comprise stable or flexible government and different societal organisations (Mishra, 2016). However, the thrust of this paper is hinged on religion as one of the unique forces that herald changes in human society.

The term religion as described by Durkheim, (1912) is an amalgamated system of beliefs and practices that are related to consecrated things. This means, things set apart as prohibited or forbidden. Durkheim, (1912) also argues that it involves a set of practices and beliefs which are united to form a single ethical community otherwise known as a Church and members who subscribe to them. Although, the above description captions the thrust of the paper, it should be noted that religion is in different forms and does not refer to Christianity alone, as illustrated by Durkheim, (1912) several forms of religion exist in human society. These include Islam, Hindus, Judaism, traditional religion such as Ifa oracle, Ogun Sango in Yoruba land, Southwest Nigeria.

In social, management and behavioural sciences, arts and humanities, the works of scholars from North America and Western Europe on social change have gained prominence in academia in Nigeria. These include Durkheim (1893), Comte, (1896), Weber, (1904), Cooley, (1930), Redfield, (1947), Tonnies, (2001) and others. But it has been closely observed that little is known about the work of Ibn Khaldun, their counterpart in Africa. The paucity of research on the works of Ibn Khaldun on the theory of social change in tertiary institutions in Nigeria may have prevented the enrichment of the literature to some extent in Africa. Besides, it could create an impression that Africans do not value the worth of some of their scholars but those of Western origin.

It is on the premise of the foregoing that this work was conceived. The article tries to discuss:

1. Life history of Ibn Khaldun and some of his contributions to knowledge;

2. Contributions of Ibn Khaldun to knowledge;

3. Ideas of western scholars on social change in comparison with that of Ibn Khaldun and highlights similarities and differences which could be used to corroborate or negate the existing literature and further research;

4. Concept of social change in the thought of Ibn Khaldun and its application to the rising and 
fallen of the Christian religion using the West and Africa as a point of reference;

5. Areas of food for thought in the change that occurred in the Christian religion; and its implications on the development of Africa.

The paper is divided into three major parts: Introduction, literature review and concluding section.

\section{Literature Review}

\subsection{Ibn Khaldun: A Brief Life History}

Ibn Khaldun lived between May 27, 1332, and March 17, 1406 in Tunisia as one of the greatest Arab historians, writers, and theorists in the $14^{\text {th }}$ century Savant (2014). Ibn Khaldun studied with the superlative education in the Maghreb where he received a classical education in Islam and Arabic linguistics. Having been introduced to mathematics, philosophy, and logic by Al-Abili of Tlemcen, he succeeded in studying the works of Averroes, Avicenna, Razi and Tusi (Muhammad, 2008). However, his passion for progressive knowledge forced him out of the court of Sultan where he was for many years and headed for Fez in the pursuit of academic excellence (Ahmad, 2017).

After his education, Ibn Khaldun struggled for a political career in the face of the political imbroglio in his country. Although, he succeeded to some extent but spent some time in prison before proceeding to exile in Qal'at Ibn Salama for 4 years, between 1375 and 1379 Savant (2014). The period availed him an opportunity to work on his then masterpiece, the Muqaddimahli Kitab al-'Ibar

In social thought, Ibn Khaldun's epistemology endeavoured to merge mysticism with spirituality by reticulating science into two major parts. The first one is religious knowledge while the second aspect is regarded as non-religious science. He advanced by classifying the non-religious knowledge into academic sciences- geometry, logic, arithmetic, astronomy, etc and supplementary sciences such as poetry, literature and language (Ahmad, 2003)

Ibn Khaldun wrote many books. One such in Sociology describes the contradiction of inactive life versus itinerant life and unavoidable loss of power that happens when warriors conquer a city that has a strong connection with the present study. His work on 'așabiyyah' which was later translated to "social cohesion" or "group solidarity", or "tribalism" has put him in the class of foremost scholars in social and behavioural sciences, arts and humanity (Rosenthal, 1958).

\subsection{Contributions of Ibn Khaldun to Knowledge: An Overview}

The contributions of Ibn Khaldun to knowledge spread across several fields of specialization (Asiyai, 2019). With respect to the foundation of the science of civilization, otherwise known as al-umran, Fahiri (2001) and Musthafa, (2015) argues that Ibn Khaldun had postulated that human beings evolved from 'the world of the monkeys' via a broadening progression that gives rise to the multiplication of 'species' before the discovery of the specific features of evolution. Apart from that, four centuries before Auguste Comte invented Sociology, Fahiri (2001) contends that Ibn Khaldun had divulged his science of culture. By this, Asiyai, (2019) believed that 'the real father of sociology' would have been conferred on him, but the reverse has been the case, probably his contributions to knowledge was not well circulated in academia like other scholars in Social sciences, e.g. Auguste Comte. Some of such contributions are briefly discussed below

\subsubsection{Human Needs}

The contributions of Ibn Khaldun to understanding human needs have greatly been influential in academia like the works of other scholars (Fahiri 2001). These include Maslow's (1943) theory of needs; Murray's (1938) theory of Psychogenic Needs cited in Cherry, (2018); Alderfer ERG theory of (1969); Herzberg (1965) two factors theory; McClelland Acquired needs theory cited in McClelland \& 
Boyatzis (1982) and others.

In his discussion on human needs, Ibn Khaldun argues that human needs are divided into the following three stages:

a. The first stage comprises of food, drinks, clothes, shelter, and other things that are derived from the nature of man. They are needed to enable human beings to survive and prevent the society from annihilation;

b. The second stage is the desire to fulfil these needs and it usually prompt man to use his knowledge and intellect to achieve them; and

c. The last stage is civilization where human beings desire luxuries because they have become more intelligent.

In societies across culture, the usefulness of human needs and the ability to meet them have been greatly explored in academic and business literature Herzberg (1965). Therefore, understanding the tenet of human needs as expounded by Ibn Khaldun and its application to social life could be significant in the following ways

Firstly, failure to meet human basic needs could be a threat to the continued existence of mankind and the society. This is because human society does not exist on its own; it owns its existence to the conglomeration of individual members living in it. Hence, if the basic needs of these persons are not met, the tendency for people to die could be very bright and in that situation, the society goes into extinction.

Secondly, in the world of work, studies have shown that employees are motivated to engage their potentials to get to the top of their careers if their needs are met (Oludayo \& Omonijo 2020). Thus, the inability of employees to meet their needs could prevent them from getting to the apex of their career and the failure could lead to frustration, moral depression, aggression etc. Apart from that, such workers may find it intricate to help industries or organisations achieve maximum productivity.

Thirdly, if workers needs are not met, some of such workers could engage their knowledge and intellect to defraud organisations to have such needs met or to acquire luxury for their own betterment. Also, the same intellect is usually employed to preserve the luxury for several years (Omonijo, Obiorah, Uche, Anyaegbunam, Shaibu and Ogunwa, 2017).

Going by the above, it could be deduced that Ibn Khaldun has sent a signal to irresponsible governments and organisations who constantly deprive their workers benefits accrued to them and good conditions of service which could make them effective at work. The signal could be a sign to them not to be surprised if they begin to witness high rate of criminal activities in their organisations because workers could engage their knowledge and intellect to participate in criminal activities in order to meet their needs, which undermine the goals of every organization and societal development.

\subsubsection{Labour Theory of Value}

Some studies have illustrated the concept of fair value in economics and its usefulness in academia (Bira \& Fatlawi, 2019). Its relevance could be linked with the value of labour that has generated extensive arguments in work organisations. To determine the value of labour, employers of labour need to be fair, but it has been observed that fairness is not fixable in capitalist societies. Some explanations in support of this could be found in the concept of the labour theory of value presented by Ibn Khaldun. Ricardo (1823) and Marx (1954)

According to Ricardo (1823), the value of a product, or the amount of any other goods for which it will exchange, depends on the relative quantity of labour which is necessary for its production, and not as the greater or less compensation which is paid for that labour. Marx (1954) argues otherwise that human labour is the cradle of economic value and that capitalists usually pay their employees less than the value which their labour has contributed to the production of goods and services. Marx (1954) advances that pay was designed to sustain employees and subject them to perpetual 
subjugation and exploitation. He also believes that pay serves as the total worth of employees and their compensation which is nothing but a mere portion, equal to the worker's means of subsistence while the residue is "surplus labour," and the value it produces (surplus-value). Marx (1954) therefore submits that the capitalists appropriate this surplus value, by exploiting their workers and to eschew exploitation therefore, Marx (1954), opts for radical revolution that will destroy the capitalists and lead to the establishment of the classless society.

For Ibn Khaldun, the profit that people realise is the value of their labour and it has nothing to do with exploitation. Ibn Khaldun submits that, through the value, the price of labour is determined, and the law of supply and demand is usually taken into consideration. Thus, the existence of many employees will usually result in large profits. Nevertheless, while Marx and Ricardo concentrated on workers and paid less attention to entrepreneurs, Ibn Khaldun focused on workers activities and the productivity of entrepreneurs.

He believed that both employees and entrepreneurs as esteemed members of society who strive to maximise the profits on investments in the form of remunerations and incomes. For him, profit is the primary motive of economic activities, since the anticipation of profit prompt the enlargement of production.

However, it could be observed that the work of the trio of Richardo, Marx, (1954) and Ibn Khaldun appeal to human logic but the presentation of Marx is much better due to his ability to pinpoint the major problem which the labour theory of value portends on workers. Considering the core principle of capitalism, which is anchored on minimization of expenditure for maximization of profits, Marx position could be justified. The workers who are responsible for the production are always at the receiving end.

\subsubsection{Team Work in Organizations}

In the discussion of Ibn Khaldun on the nature of production, the need for cooperation among workers was brought to bear. For effective and efficient production to be actualized in organisations which involve many complex stages that overlap like rings, the efficacy of interdependence and interaction among the stakeholders should not be overemphasized. This is an indication that nobody can ever be an island on his or her own and it goes to support Marx and Engel, (1882) idea on social relations in the course of the production of goods and services. It also shows that teamwork is a major requirement for maximum productivity (Pauliene, Diskiene \& Matuzeviciute, 2019). The collective efforts of three persons could be more productive in work organisations more that the efforts of uncoordinated ten persons. In modern societies, specialization has made productivity easy and timely but without solid relationship and cooperation, the end process of production could be negatively affected.

The social life reality of this thought is hinged on the fact that workers can enjoy working together as a team. The togetherness could help them to build the spirit of socialization and interdependence at work. Apart from that, working as a team can help workers to grow as they keep on learning from each other and develop vital skills. It can equally give room for developing a sense of purpose for motivation and fulfillment.

\section{Social Change}

Central to Ibn Khaldun theory of social change is the idea that religion, leadership, and power are strongly responsible for social change. He demonstrated this idea in his work on Asabiyyah. According to him, religion, power and leadership contribute to the rising of Asabiyyah while vital factors such as wealth and corruption are responsible for its decline. With this, Ibn Khaldun examined the solidity ascends instinctively in clans and other minor kinship collections and demonstrated how it could be strengthened and distended by a spiritual ideology. This means the impact of cohesion on power in Asabiyyah, its negative seed of destruction and its subsequent 
replacement with a new-fangled group or kingdom is bound by a tougher, younger and more dynamic cohesion (Morris, 2015).

By this, Ibn Khaldun has not only demonstrated the contradiction that exists between lethargic life and itinerant life, but also illustrated the concept of a generation, and the inexorable loss of power that desert warriors usually experienced when they conquer a city, just like the rise and fall of ancient empires such as Roman and British (Linton, 2015; James, 1997). It therefore applies that when a society or an individual experience a great civilization or prosperity; presumably, the dominant culture or person in its or his region, its/her high point is followed by a period of decadence.

According to Rana and Sultana, (2015) work of Ibn Khaldun on Asabiyah has been greatly influenced by Islamic thinking where simple people adhere to a new religious belief by nature while the rich people undermine the Islamic values and living in luxury. Besides, the work suites the bedouin and resentful of sedentary materialistic (Ettaref) societies that had a strong sense of solidarity. In these societies, Al-asabiyah served as the social bond while the Muslim brotherhood was the binding factor for the multiethnic society (Rana and Sultana, 2015).

\subsection{The Differences in Societal Changes and Authors}

According to Abraham (1973), Western scholars of sociology greatly focused on social change as it concerns modernization, development and societal evolution since its origin in France in the $18^{\text {th }}$ century. He used Comte's law of the three stages to illustrates how human society could evolve and Spencer's notion of Linear Evolution as an indication of great expression of interest among scholars from the West on the phenomenon of change, mostly after the $2^{\text {nd }}$ world war. Hence, the West has amassed an inspiring amount of literature not only on the sociology of social change but also in areas of societal development and underdevelopment while Ibn Khaldun was entranced by the rapid phenomena of change which occurred in Maghreb in the $14^{\text {th }}$ century in Arab (Abraham 1973). The outcome of which the dynamic nature of transformation in villages, towns, and cities (bedouin society and resentful of sedentary) was brought to bear and it is similar to the approach of most western scholars on social change (see Table i).

Table i: Societal Categorisation by Different Authors

\begin{tabular}{|c|c|c|c|c|c|c|}
\hline SN & Authors & Types of Societies & & & & \\
\hline 1 & Spencer, (1979) & Simple & Compound Society & Doubly Compound & Trebly Compound & - \\
\hline 2 & Marx \& Hegel (1882) & Slavery & Feudalism & Capitalism & Socialism & Communism \\
\hline 3 & Rostow, (196o) & Traditional & Precondition for take-off & Take-off stage & Stage of maturity & $\begin{array}{l}\text { Stage of mass } \\
\text { consumption }\end{array}$ \\
\hline 3 & Comte (1896) & Theological or fictitious & Metaphysical or abstract & Scientific or positive & - & - \\
\hline 4 & Ibn Khaldun & Bedouin society & Resentful of sedentary & - & - & - \\
\hline 5 & Durkheim, (1893) & Mechanical Solidarity & Organic Solidarity & - & - & - \\
\hline 6 & Tonnies (2001) & Gemeinschaft & Gesellschaft & - & - & - \\
\hline 7 & Weber, (1904) & Traditional & Rational & - & - & - \\
\hline 8 & Cooley, (1930) & Primary & Secondary & - & - & - \\
\hline 9 & Redfield, (1947) & Folk & Urban & - & - & - \\
\hline 10 & Becker, (196o) & Sacred & Secular society & - & - & - \\
\hline 11 & Lerner, (1958) & Traditional & Modern & - & - & - \\
\hline 12 & Parson, (1937) & Particularism & Universalism & - & - & - \\
\hline
\end{tabular}

Source: Compiled by the researchers, (2020)

Given this, Ibn Khaldun's belief in the transformation of human society from a primitive to a more complex type is key and corroborates several other thoughts in the past and contemporary history of human societies. Nevertheless, his idea greatly differs when compared with Karl Marx idea on teleological advancement for human society through material forces (Marx and Engels, 1882) and Rostow, (1960) stages of economic growth. Although his typology idea concurs with some other 
scholars in Table $\mathbf{i}$, his argument that there is no definite end of stages in human history makes his perspective unique.

Besides, contrary to Herbert Spencer, Karl Marx and Auguste Comte who contend that society passes through four and three stages of development respectively, Ibn Khaldun in his work on Asabiyyah divided human society into two. The 'Asabiyyah was later translated to 'group solidarity' of 'social cohesion', or 'tribalism' and it means translation of a society from a primate nature (badawah) to a more complex type (hadarah). In other words, badawah connotes tribal life that is prominent in remote regions and mountains while Hadarah means civilization predominantly found in cities.

As argued by Toynbee (1956), the work of Ibn Khaldun, stands out because he was never inspired by any predecessor nor found any allied among his contemporaries nor sparked nothing like inspiration on any successor. Yet, his prolegomena (the Muqaddima) which he created and formulated to the universal history is considered a philosophy of history and undoubtedly the greatest study of its kind that has never been replicated in academia Toynbee, (1956).

\subsection{Social Change in Christian Religion}

The thought of Ibn Khaldun on Asabiyah could be used to express the social life reality of the emergence of the Christian religion from the West and its introduction to African countries several decades ago. Temitope, (2015) argues that Christianity originated from the West and grew to become a powerful weapon of life transformation across the world. Its positive impacts in African in the wave of colonialism are undeniable in areas of abolition of obnoxious traditional practices, such as human sacrifice, killing of twin babies, bloody boxing, cattle rustling, betrothal and women subjugation (Olokoyo, Efobi, George and Beecroft, 2014).

It could also be sued to explain decline of the Christian religion in the West and its sudden rise in Africa. The rate at which the faith suddenly gained prominence in African previously known for paganism with massive Church attendance and its decline across Europe (see Fig. i) once firmly populated by Christians and the rising of Christian ministries is beyond human comprehension and understanding. Africa, although, the least economically, socially, politically, technologically, educationally developed continent globally suddenly emerged the least in the rate of Church closure (Fig. i) and topmost in the rate of Church growth (Temitope, 2015).

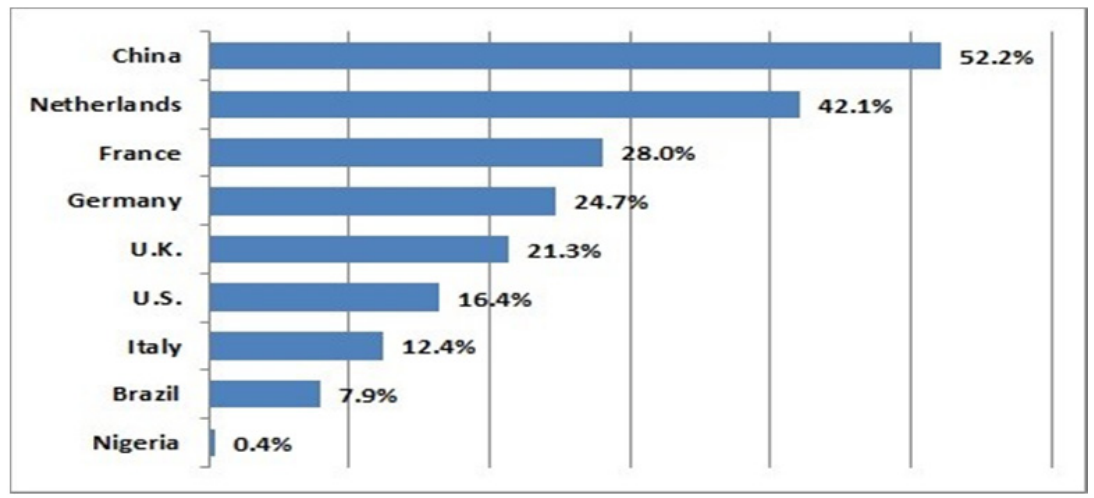

Fig. i: The Rate of Church Closure

On this note, Barrett, (2018) remarks, in the $20^{\text {th }}$ century, Christianity in Africa has grown from its elementary level in 1900 to a critical level in the year 2000 which represents a shift in the focus of its severity from the West to Africa.

The shift could be regarded as the greatest shock which some scholars of religion, history, 
development etc. may not be able to recover from for a very long time. The shock could also be hinged on the fact that Africa, that is been considered unimportant in term of development, the continent scorned, dispossessed, flattened upon, relegated, and shamed in many ways, sudden emergence as the inspiration of Christian mission and evangelisation in the world (Asamoah-Gyadu, 2008). Besides, its solidification of control over the conquered Christian religion and her attraction to its in more refined aspects is hard to imagine (Nunn, 2010).

\section{Food for Thought in the Change in Christian Religion from the West to Africa}

The fall of Christianity in the West and its sudden rise in Africa has brought to the fore the social life reality of Ibn Khadun on a society that once attained the highest level of civilization and also experienced a period of decay. Its social reality goes to reinforce the dictum which says, nothing is permanent in life.

By this, individuals or nations who might be experiencing success in any area of life should exercise caution because such success might not last forever. However, the positive impact of the success on humanity could translate from one generation to another as shown in the introduction of Christianity to Africa by the Western Missionaries. Had it been it was not introduced to Africa at a cost, perhaps, the continent might not have witnessed the dramatic transformation she has witnessed in the last century. Such transformation is evident in the areas of the abolition of obnoxious traditional practices, such as human sacrifice, killing of twin babies, bloody boxing, cattle rustling, betrothal and women subjugation as illustrated by Olokoyo, Efobi, George and Beecroft, (2014). Hence, any advantaged position that one may occupy per time, should be employed to encourage others to reach and attain their goals through the necessary assistance that could be rendered.

The fall of Christianity in the West Beinart, (2017) could be attributed to moral decadence in the wake of science and technology. All through human history, new technologies have had a significant impact on culture Furedi, (2014) and the Christian religion is not an exception. The addiction of Westerners to science and technology has brought about the abandonment of fellowshipping with God (McSwain, 2013). As Westerners become more comfortable with engaging social media and attending social gatherings like clubhouses, cinema, watching television than attending Church programmes, acquiring positive virtues which may keep them in constant relationship with God are drastically reduced (Aliaj, Nurja, Tahiri \& Muca, 2019; Changsong, 2019). To continual develop Christian virtues and have a good relationship with God demand maintaining constant interaction with brethren (fellowship), ensuring regular reading of Bible and other Christian literature for the renewal of spirit and its maintenance. This goes to show that God does not tolerate truancy but dedication to His words and kingdom.

The rise of Christianity in Africa could also give an understanding that underrating a set of people is not only ungodly but also unwise and should be discouraged with all seriousness in as much as Africa that was ridiculed in the past as pagans are now noted for high Church attendance (Temitope, 2015).

The rise of Christianity and the multiplication of Churches in Africa in the contemporary is seemed not to have a positive effect on corruption. Thus, while Western nations are being raked low in corruption, African countries keep on taking the lead (Corruption Perception Index, 2018; Asiyai, 2020). Before the introduction of Christianity when Africans were worshipping deities or gods, the rate of corruption was very low compared with the contemporary that Church attendance is increasing (Adeboye, 2020). Presently, Adeboye (2020) argues, people do not consider sin as untouchable as it was several years ago when there were fewer Churches.

The foregoing corroborates Ibn Khaldun, position that corruption is one of the strong forces behind the fall of the civilized regions, therefore if care is not taken, it could result in the fall of the Christian religion in Africa.

African is witnessing multiplication of Churches while the West that introduced the same to the Africans is experiencing the high rate of Church closure (McSwain, 2013) and the Church premises are 
now being used for production of goods and services (Sherwood, 2018). Consequently, the West is highly industrialised while African is poorly industrialised. This, may not be unconnected with the low rate of unemployment and poverty in the West and high rate of joblessness, lack and want in Africa (Beegle, Christiaensen, Dabalen \& Gaddis 2016)

The foregoing, most especially the escalation of corruption and social vices could give the impression that Christianity introduced to Africans several decades ago has been polluted in the contemporary. Thus, it may no longer be used to corroborate the argument of Durkheim, (1912) on religion being an amalgamated system of beliefs and practices that are related to consecrated things (those things set apart as untouchable or forbidden). This is because it seems things set apart as prohibited or forbidden-immorality, corruption, general indiscipline are now escalating in Christianity in Africa and it appears they have been accepted as parts of Christian faith. Probably, most Christian preachers in Africa are not subscribing to scriptural doctrines strictly due to their interest in members offerings and tithes. This could be used to explain why they lay much emphasis on prosperity to the detriment of holy living.

\section{Implications for Africa's Development}

With the high level of corruption, it could be very difficult for Africa to experience development inspite of her abundant natural resources and multiplication of Churches. Dwelling on Seers (1969), the term development involves the capacity of human society to reduce inequality, unemployment and poverty. The fact remains that poverty, inequality, unemployment cannot be reduced in societies where insincerity is escalating but in societies where proper discipline and integrity become most peoples lifestyle. It gives room for success and not stagnation or backwardness. For that matter, nations who possess persons of high integrity (Japan, China, South East Asia) have been able to transform their societies from tradition to a modern type than those that possess corrupt officials (African countries). The analogy is very simple, the wages of sin is death, but the gift of life is everlasting life. The type of death in this context might not be immediate and physical, it could take a long time and it could manifest in all kind of afflictions. This might be the major reason behind Africans developmental challenge amid natural endowments.

Thus, the development that Africans need has to commence with the transformation of human character in line with God's values (Musopole, 1997; Myers, 1999; Mwije, 2012). Until Africans sense of identity is distorted and disempowered and be replaced with the truth, to make progress could be practically impossible; it is the righteousness that exalts a nation, sin is a reproach to many people.

\section{Concluding Remarks}

This study examined the concept of social change in the thought of Ibn Khaldun and its applicability to the Christian religion. On one hand, views of other prominent authors of social change were examined and came up with the fact that while European sociologists believe that human society follows evolution in a linear arrangement, Ibn Khaldun perceived evolution of Arab Islamic societies cynic in nature. Apart from that, Ibn Khaldun presented a strong relationship between the widespread of extreme materialism, / luxury in Arab countries and their weakness and unavoidable downfall but such a link is barely found in the sociology of western scholars. By this, Ibn Khaldun has succeeded in identifying what could be regarded as the rhythmic repetition of the rise and fall in human civilization, and evaluated factors responsible for both. His main influence on history is discernable by the fact that, while other earlier scholars construed history basically in a political context, he accentuated ecological, economical and sociological, psychological factors governing social life.

Concerning the Christian religion, as it relates to the West and Africa, the work of Ibn Khaldun has reinforced the dictum that 'change is the only thing that is permanent in life'. In 19oo, in the wake of colonialism, it could be very intricate to imagine Africa, known for paganism dominating the West 
that introduced Christian religion to Africans, a century after. Apart from that, it could be very difficult to imagine African countries known for probity and integrity in the era of worshipping deities now being ranked among the topmost corrupt nations in the era of high church attendance while the societies that are witnessing the closure of Churches are being rated the least corrupt nations. This could give the impression that Christianity in contemporary Africa has been polluted and things that were generally set apart as forbidden-immorality, corruption, fornication, adultery, stealing, indecent behaviours etc.in the early day Christianity are no longer set apart in the contemporary but embraced as parts of Christianity. This paper compares this paradox with corruption which Ibn Khaldun postulated as the cause of the fall of the conquered region and it may likely result in the fall of Christianity in the region.

\section{Acknowledgments}

This work was supported in the payment of the publication fee by the Covenant University Centre for Research and Innovation Development (CUCRID)

\section{Reference}

Abraham, H. (1973). Origins and Growth of Sociology. London: Penguin Books, p. 194-7.

Adeboye, E. A. (2020). Open Heavens; A Guide to a Close Fellowship With God, Volume 20. Redemption Camp, Ogun-State: Open Heavens International Centre.

Ahmad, Z. (2003). The epistemology of Ibn Khaldun. New York: Routledge Curzon. ISBN 978-0-415- 61275-3.

Ahmad, Z. (2017). A 14th Century Critique of Greek Philosophy: The Case of Ibn Khaldun. J Hist Sociol., 30: 57-66. https://doi.org/10.1111/johs.12151

Alderfer, C. P. (1969). An empirical test of a new theory of human needs. Organizational Behavior and Human Performance, 4, 142-175.

Aliaj, B., Nurja, F., Tahiri, E., \& Muca, F. (2019). An Investigation Study of TV Watching for Albanian Children and Teenagers Living in Tirana. Journal of Educational and Social Research, 9(3), 291. Retrieved from http://www.richtmann.org/journal/index.php/jesr/article/view/10512

Asamoah-Gyadu, K. (2008). African-led Christianity in Europe: Migration and Diaspora Evangelism. Lausanne World Pulse Archives

Asiyai, R. I. (2020). Corruption in Secondary Schools: Administrative Strategies for Its' Management. Journal of Educational and Social Research, 10(1), 106. https://doi.org/10.36941/jesr-2020-0010

Asiyai, R. I. (2019). Deviant Behaviour in Secondary School and its Impact on Students' Learning. Journal of Educational and Social Research, 9(3), 170. Retrieved from http://www.richtmann.org/journal/index.php/jesr/article/view/10499

Barrett, D. (2018). The Explosion of Christianity in Africa. Available on https://www.christianity.com /church/church-history/timeline/2001-now/the-explosion-of-christianity-in- africa-11630859.html

Becker, H. (1960). Normative Reaction to Normlessness. American Sociological Review, 25(6): 803-810

Beegle, K; Christiaensen, L; Dabalen, A; Gaddis, I. (2016). Poverty in a Rising Africa. Washington, DC: World Bank. (C) World Bank. https://openknowledge.worldbank.org/handle/10986/22575 License: CC BY 3.o IGO.

Beinart, P. (2017). The culture war over religious morality has faded; in its place is something much worse. Available on https://www.theatlantic.com/magazine/archive/2017/04/breaking-faith/517785/

Bira, D. N. K., \& Al Fatlawi, L. N. M. (2019). The role of using fair value on relevance and representation faithfulness of accounting information in accordance with the Common Conceptual Framework (FASB- IASB). Restaurant Business, 118(12), 142-165. Retrieved from https://journals.eduindex.org/index.php/rb/article/view/13092.

Changsong, W. (2019). Cinema Attendance and Cinema-Going Audience in Malaysia. MEDIA WATCH 10 (3) 539549. DOI: $10.15655 / \mathrm{MW} / 2019 / \mathrm{V}_{10} \mathrm{I}_{3} / 49682$

Cherry, K. (2018). Murray's Theory of Psychogenic Needs How Needs Might Influence Personality. Available on https://www.verywellmind.com/murrays-theory-of-psychogenic-needs-2795952. Accessed on December 7, 2018

Comte, A. (1896). The philosophy of positivism. New York: Free Press.

Cooley, C. (1930). Sociology Theory and Social Research. New York: Henry Holt and Company

Corruption Perception Index, (2018). First launched in 1995, the Corruption Perceptions Index has been widely credited with putting the issue of corruption on the international policy agenda. Available on https://www.transparency.org/research/cpi/overview Retrieved on Jan. o6, 2020 
Cosma, S. (2009). "Ibn Khaldun's Economic Thinking". Ovidius University Annals of Economics (Ovidius University Press) XIV: 52-57

Durkheim, E. (1912). The Elementary Forms of the religious life. Translated by Joseph Swain. London: George Allen \& Unwin Ltd. p. 201

Durkheim, E. (1893). The Division of Labour in Society. Translated by W. D. Halls. Houndmills: MacMillan

Faroog, A. F and Rubasundram, C. A. (2020). Bribery \& Corruption: A Comparative Study between Malaysia, USA and South Korea. TEST Engineering \& Management, 82: 1170 -1180

Faridah, H. M. (2018). Ibn Khaldun and James Adams: The real father of Sociology and Mother of Social Works. Faculty of Business Management. Universiti Teknologi Mara, Malaysia.

Furedi, (2014). How The Internet and Social Media Are Changing Culture. Available on https://www.aspen.review/article/2017/internet-social-media-changing-culture/

Herzberg, F. (1965). The motivation to work among Finnish supervisors. Personnel Psychology, 18, 393-402.

Gyan, E., Baah-Korang, K., McCarthy, P and McCarthy, P. (2015). Causes of Indiscipline and Measures of Improving Discipline in Senior Secondary Schools in Ghana: Case Study of a Senior Secondary School in Sunyani. Journal of Education and Practice, 6(11): 19-26

James, L. (1997). The Rise and Fall of the British Empire. England: St. Martin's Griffin

Kinoti, G., \& Kimunyu, P., (eds.), (1997), Vision for a Bright Africa: Facing the Challenges of Development, First Ed., Published by International Fellowship of Evangelical Students (IFES) and The African Institute for Scientific Research and Development (AISRED), Nairobi, Kenya, pp. 18- 37 \& 282-312

Lerner, D. (1958). The Passing of Traditional Society: Modernizing the Middle East. New York: Free Press.

Linton, B. (2015). The Rise And Fall Of The Roman Empire: Life, Liberty, And The Death Of The Republic Kindle Edition. UK: Make Profits Easy LLC

Marx, K. (1954). Capital. Moscow: Progress Press

Marx, K. and Engels, F. (1882). Communist manifestos. Progress Publishers: Moscow.

Maslow, A. H. (1943). A theory of human motivation. Psychological Review, 50, 370-396

McClelland, D. C., \& Boyatzis, R. E. (1982). Leadership motive pattern and long-term success in management. Journal of Applied Psychology, 67, 737-743.

McSwain, S. (2013). Why Nobody Wants to Go to Church Anymore. Available on https://www.huffpost.com/entry /why-nobody-wants-to-go-to_b_4086016?guccounter=1\&guce_referrer=aHRocHM6Ly93d3cuYmluZy5jb20v \&guce_referrer_sig=AQAAACdldfDDURPG28znqxLtTmCH8X27as7bp161F3AJeWPFjcHoTjDNoS-3-kKG4 us7tcXQmShW4Gu8TdZJWoTLfK1Ueel 3 RCxNN2IK6VQGlxoVfYoYzXcaP_ftn-ahudkkasK1g4Nd4ksZtGgmcn _f3Pg4oTfisWEivkTOYpB6FB8h

Mwije, S. (2013). "Traditional Practices are Solemn Impediments to Development: Ideas from Myers, L. B., (1999), Walking with the Poor: Principles and Practices of Transformational Development, Maryknoll”, New York, USA: Orbis Books. Retrieved 15/o6/2019: https://www.academia.edu/17831417/Traditional_Practices_are _Solemn_Impediments_to_Deve lopment

Myers, L. B., (1999), Walking with the Poor: Principles and Practices of Transformational Development, Orbis Books, Maryknoll, New York, USA

Mishra, C. (2016). Impact of Social Change on Community- A Case Study of The Snake Charmers Kela) of Padmakesharipur, Odish. International Journal of Current Research, (8)12: 44061-44065

Morris, S. (2015). Europe's Abandoned Churches a Warning for America. Available on https://www.summit.org/resources/articles/europes-abandoned-churches-a-warning-for-america/

Muhammad, H. (2008). "Ibn Khaldun: His Life and Work". Islamic Philosophy Online. Retrieved 20o8- o9-19.

Muslim Heritage, (2017). "Ibn Khaldun: His Life and Works". muslimheritage.com. Retrieved 2017-12-05

Musthafa, N. (2015). Origin and Evolution of Human Society in Ibn Khaldun's Philosophy of Human Development. Centre for Islamic Pluralism. Available on http://www.islamicpluralism.org/2469/origin-and-evolution-ofhuman-society-in-ibn

Nigeria. Journal of Humanities And Social Science (JHSS), 5(6): 51-57

Nunn, N. (2010). Religious Conversion in Colonial Africa. American Economic Review: Papers \& Proceedings 100 (May 2010): 147-152. http://www.aeaweb.org/articles.php?doi=10.1257/aer.100.2.147

Oludayo, A. O. \& Omonijo, D. O (2020). WORK-LIFE BALANCE: THE RELEVANCE OF SOCIAL SUPPORT. Academy of Strategic Management Journal, 19(3):1-10

Olokoyo, F.O; Efobi, U.R; George, T.O and Beecroft, I. (2014). Land deals and sustainable income: The case of a rural community in Ogun state, Nigeria. Handbook of Research on In-Country Determinants and Implications of Foreign Land Acquisitions, December 31: 322-336 
Omonijo, D. O., Obiorah, C. B., Uche, O. O. C., Anyaegbunam, M. C., Shaibu, A. O and Ogunwa, C. E. (2017). Exploring Social Theories in the Study of Insecurity in Contemporary Nigeria. The Journal of Social Sciences Research, 3(7): 59-76, Open Access

Omonijo, D. O. Anyaegbunam, M. C., Okoye, E.; Okunlola, B. O., Adeleke, V. A., Olowookere, E. I. Adenuga, O. A and Olaoye (2019). The Influence of Genital Mutilation on Women's Sexual Activities in Oke-Ona, Community, Abeokuta, Nigeria. Journal of Educational and Social Research, 8(3): 254-267. Doi: 10.2478/jesr2019-0044

Onoyase, A., \& Ebenuwa-Okoh, E. E. (2018). Relationship among Adolescents' Characteristics, Peer Group Influence and Anti-Social Behaviour. Journal of Educational and Social Research, 8(3), 9. Retrieved from http://www.richtmann.org/journal/index.php/jesr/article/view/10312

Parsons, T., (1937). The Structure of Social Action, New York: McGraw-Hill

Pauliene, R., Diskiene, D., \& Matuzeviciute, E. (2019). Complex Approach on Multicultural Teams Management \& Leadership. Journal of Educational and Social Research, 9(2), 8. Retrieved from http://www.richtmann.org/journal/index.php/jesr/article/view/10428

Rana, J and Sultana, T. (2015). Ibn Khaldun's Theory of Social Change: A Comparison with Western Social Thoughts. Third Biruni Interdisciplinary International Conference At: FARS Hotel \& Resorts Volume: Book of Abstracts $3^{\text {rd }}$ Biruni Interdisciplinary International Conference, p.27. DOI: 10.13140/RG.2.1.2841.9922

Rejulin, V. J. K. (2019). Cultural Oppression in Chinua Achebe's No Longer at Ease. Think India Journal, 22(35): 5357. Retrieved from https://journals.eduindex.org/index.php/think-india/article/view/18249

Redfield, R. (1947). "The folk society”, American Journal of Sociology, LII

Ricardo, D. (1871). On the Principles of Political Economy and Taxation. Piero Sraffa (Ed.) Works and Correspondence of David Ricardo, Volume I, Cambridge University Press, 1951, p. 135.

Rosenthal, F. (1958). Ibn Khaldun the Muqaddimah. An Introduction to History. Translated from the Arabic. Bollingen Foundation Series xliii. Princeton University Press.

Rostow, W. W. (1971). Etapas do desenvolvimento econômico. Rio de Janeiro: Zahar Editores.

Savant, S. B. (2014). Genealogy and Knowledge in Muslim Societies: Understanding the Past. Edinburgh University Press. p. 77.

Seers, D. 1969. The Meaning of Development. International Development Review 11(4): 3-4.

Sherwood, H. (2018). "'Christianity as default is gone': the rise of a non-Christian Europe". The Guardian. London Spencer, H., (1979). Principles of Sociology, Vol.1, New York: D. Appleton.

Temitope, (2015). Nigeria Ranks $9^{\text {th }}$ in List of Most Religious Countries in the World. Available on http://www.nigerianmonitor.com/list-of-most-religious-countries-in-the-world/

Tönnies, F (2001.) Community and Civil Society. Cambridge: Cambridge University Press

Toynbee, A. (1956). The Study of History (London: Oxford University Press, 1956), III, 322.

Weber, M. (1904). “Objectivity in Social Science and Social Policy” in The Methodology of the Social Sciences, E. A. Shils and H. A. Finch (ed. and trans.), New York: Free Pres 